J. Product. \& Dev., 24(1): $181-190$ (2019)

\title{
BIOCHEMICAL EVALUATION OF SOME FOLIARS ON YIELD AND QUALITY OF SOYBEAN SEEDS
}

\author{
Abdelaziz L. Sharaf \\ Department of Soil and Water, Faculty of Technology And Development, \\ Zagazig University, Egypt.
}

\section{ABSTRACT}

A field experiment was carried out at the Agronomy Farm of Faculty of Technology and Development Zagazig University, Egypt, to Study the effect of Novatreen and potassen foliar on the grain yield and quality of soybean seeds.

Soybean plants were sprayed with two foliar nutrients, at concentrations were $0.2 \%$ and $0.4 \%$ respectively. All treatments significantly increased the grain yield and plant performance (No, of pods per plant, No, of seeds per pods and weight of 100 seeds) .Insoluble nitrogen contents recorded a slight decrease by foliar potassen. Total nitrogen in seeds was increased with novatreen foliar. The potassen foliar was increased water soluble protein content, while decreased the protein fraction solubilized in both acetic acid and $0.1 \mathrm{~N} \mathrm{NaoH}$ solvents. Also, novatreen foliar slightly decrease of total protein content.

The pattern of soybean proteins showed two main fractions (7S and $11 S$ globulins) with their constituting subunits. Oil content of soybean seeds slightly decreased with novatreen foliar, but potassen foliar increased the oil content of soybean seeds. A slight differences were noticed with acid values, saponification and iodine values. The highest values of both saponification and iodine were obtained by 0.2 $\%$ foliar potassen. Both foliars improved the contents of $P, K$ and $N a$ , but reduced the contents of Fe and Mn in seeds.

Conclusively, It is recommended to spray the novatreen and potasen compound on the plants after 30 days of cultivation with a concentration of $0.4 \%$ to obtain the highest productivity of the seed yield as well as the quality of the protein content, oil and nutrients necessary for the process of metabolism in the plant.

Key words: Biochemical Evaluation, Foliars, Yield \& Quality, Soybean Seeds. 


\section{INTRODUCTION}

Soybean is one of the most important legume crops in the world, as well as, in Egypt, where considering a good source of oils and protein for human and animals nutrition. Foliar compounds are substances that influence physiological processes of plant at very low concentration. Heidarian et al (2011), found that foliar application of $(\mathrm{Zn}+\mathrm{Fe})$ had appositive effect on seed yield ,number of pods per plant and weight of 1000 seeds ,also, increased the protein content of seeds. Yosuf et al (2012) stated that $\mathrm{N}$ or $\mathrm{N}+\mathrm{Fe}$ applications on soybean plant were recorded maximum values of seed yield. Potassen spray application on soybean plant slightly increased both yield and protein content of seeds as stated by Antonio (2012). Mudlagiri et al (2012) stated that seed protein, oil content, fatty acids and mineral contents were increased in soybean seeds by the foliar compounds $(\mathrm{Ca}+\mathrm{Fe})$ and $(\mathrm{Si}+\mathrm{Fe})$ and they were noticed an increase of oleic acid ,but there was a decrease of linoleic acid among fatty acids composition of oil .Faisal et al (2013) noticed that Fe and Mo applications on soybean plant had a significant effect on seeds yield and its chemical composition, where this application was increased protein content of seeds .

Foliar application of potassen at height level on soybean plants has no effect on protein ,oleic acid contents and total isoflavones of soybean seeds as evaluated by Nacer et al (2013). Mannan (20-14) found that the foliar of elements application at the pod stage of soybean plant growth was more effective on the yield, oil and protein contents of seeds. Manju et al (2014) found that potassen fertilizer, when applied as foliar on soybean plant at high level recorded an increase of protein content and percentages of linoleic, palmatic and stearic acids in soybean seeds compared with control.

Therefore, the aim of this investigation was to evaluate the effect of novatreen and potassen foliars on grain yield and quality of soybean crop.

\section{MATERIALS AND METHODS}

The field experiment was carried out in the Agronomy farm of Faculty of Technology and Development, Zagazig university, Zagazig, in Gazala, Egypt, 2018. A complete randomized Block design was applied with three replicates of each treatment of Giza 111 variety of soybean plants . The area of each plot was $3 \mathrm{~m}^{*} 3.5 \mathrm{~m} \quad$ (1/ 400 per feddan). The novatreen \& potassen foliars which parchased from local market, were applied as follow :

1- Control

2- $0.2 \%$ Novatreen, containing $5 \% \mathrm{~N}, 5 \% \mathrm{P}, 5 \% \mathrm{~K}, 0.4 \% \mathrm{Fe}, 0.4 \% \mathrm{Zn}$, $0.3 \% \mathrm{Mn}, 0.05 \% \mathrm{~B}$. 
3- $0.4 \%$ Novatreen containing the same elements in treatment No.2.

4- $0.2 \%$ Potassen, containing $30 \% \mathrm{~K}_{2} 0,5 \% \mathrm{P}$.

5- $0.4 \%$ Potassen containing the same elements in treatment No.4.

The foliars were applied after 30 days from sowing date. At full maturity soybean crop was harvested. The grain yield was determined and stored under recommended condition for chemical analysis.

\section{Chemical analysis}

Nitrogen fractions was determined by Microkjeldhal method as stated by A.O.A.C.( 1970). Protein fractions were fractionated successively using three solvents, dionized water, $70 \%$ acetic acid and $0.1 \mathrm{~N} \mathrm{NaoH}$, then every fraction was determined using total nitrogen method as previously mentioned. The electrophoresis analysis of seed proteins was carried out according to Laemmle (1970). Oil was extracted from the seeds and acid value, saponification value ,Iodine value and free fatty acids were determined as stated by A.O.A.C. (1970). Phosphorus was determined according to the method of Agiza et al (1960). Potassium and sodium were determined according to the methods applied by Hamdia (2013). Microelements were determined using the atomic absorption apparatus according to the method Chapman and Parker(1961 ).

\section{RESULTS AND DISCUSSION}

Some plant performance of soybean plant was recorded in Table (1). It can be noticed that novatreen application significantly increased pods per plant either with $0.2 \%$ or with $0.4 \%$ (158.80 and 167.81 respectively, as well as Potassen application increased pods per plant at the same concentrations (179.22 and 194.25 respectively ) and Potassen was recorded highest values compared with novatreen application or with control . Grain per plant values in the same table showed that highest value was recorded by novatreen application at $0.4 \%$ (2.99)followed by potassen values (2.96),(2.97) with concentration (0.4 and $0.2 \%$ respectively) and novatreen $(0.2 \%)$, which recorded (2.95) compared with value of control (2.83).

Weight of 100 seeds values were tabulated on Table (1). It showed that both applications of novatreen and potassen at $0.2 \%$ gave highest values (19.95 and 18.53 , respectively) followed by values of $0.4 \%$ for both two foliars (17.95 and 17.35 respectively) . Result of grain yield was showed on Table (1), where potassen and novatreen with $0.4 \%$ were Ogave highest values (42.60 and 41.53, respectively), while values of two folairs with $0.2 \%$ were 41.00 and 33.08 , respectively). These results were in agreement with those reported by Heidrain 
Table (1):-Effect of novatreen and potassen foliars on yield characteristics crop.

\begin{tabular}{|l|c|c|c|c|}
\hline \multicolumn{1}{|c|}{ Treatments } & $\begin{array}{c}\text { No. of pods } \\
\text { Per } \\
\text { plant }\end{array}$ & $\begin{array}{c}\text { No. of grain } \\
\text { Per } \\
\text { pods }\end{array}$ & $\begin{array}{c}\text { Weight of } \\
\mathbf{1 0 0} \text { grain } \\
(\mathbf{g})\end{array}$ & $\begin{array}{c}\text { Grain yield } \\
\text { Per plant } \\
(\mathbf{g})\end{array}$ \\
\hline 1- Control & 123.51 & 2.83 & 16.68 & 32.14 \\
\hline 2- 0.2\% novatreen & 158.80 & 2.95 & 19.95 & 33.08 \\
\hline 3- 0.4\% novatreen & 167.81 & 2.99 & 17.95 & 41.53 \\
\hline 4- 0.2\% potassen & 179.22 & 2.96 & 18.53 & 41.00 \\
\hline 5- 0.4\% potassen & 194.25 & 2.97 & 17.35 & 42.60 \\
\hline F-test & $* *$ & $*$ & $* *$ & $* *$ \\
L.S.D > 0.05 & 13.76 & 0.081 & 1.233 & 3.509 \\
L.S.D > 0.01 & 20.08 & 0.118 & 1.799 & 5.121 \\
\hline
\end{tabular}

et al, (2011);Yosef et al. (2012) and Abd-elmohsin (2016). Data responded effect of novatreen and potassen foliars application on nitrogen fractions illustrated on Table (2). It can be noticed that potassen application had positive effect on soluble nitrogen with $0.4 \%$ and $0.2 \%$ concentrations (0.494 and $0.485 \mathrm{~g} / 100 \mathrm{~g}$ respectively) comparing with control (0.469)and highest than novatreen application with the same concentration $(0.441$ and $0.454 \mathrm{~g} / 100 \mathrm{~g}$ respectively).Insoluble nitrogen percentages highly affected with novatreen application either with $0.2 \%$ or with $0.4 \%$ (6.23 and $6.31 \%$ respectively) comparing with control $(6.15 \%)$,but higher than those values of potassen applications $(6.11 \%$ and $6.08 \%$ for two concentrations respectively).Also it can be noticed that total nitrogen percentages were positively affected with novatreen application, where two concentrations were recorded higher values than control and potassen application (6.68 ,6.75,6.62, 6.60 and $6.75 \%$ respectively), Table (2). These results showed that novatreen applications improved accumulation of insoluble nitrogenous compounds were accordance with obtained by Mudlagiri et al. (2012) and Manan (2014). Also, it can be noticed that accumulation of insoluble nitrogen fraction due to an increase in protein synthesis as stated by Abdelmohsin ,(2016).

The data in Fig (1) showed electrophoretic pattern of soybean seed protein as affected by two concentrations of novatreen or of potassen foliar ,where lane 1 is control ,lane 2 is $0.2 \%$ novatreen, lane 3 is 0.4 novatreen, lane 4 is $0.2 \%$ potassen lane 5 is $0.4 \%$ potassen. The pattern of soybean proteins shows main fractions ( $7 \mathrm{~S}$ and $11 \mathrm{~S}$ globulins) with their constituting subunits. The molecular masses of $11 \mathrm{~S}$ globulin subunits are 21 and $34 \mathrm{KD}$ ,corresponding the basic and acidic subunits. The molecular mass of 7S. 
Table(2): Effect of novatreen and potassen foliars on nitrogen fractions of soybean seeds .

\begin{tabular}{|l|c|c|c|l|}
\hline \multicolumn{1}{|c|}{ Treatments } & $\begin{array}{c}\text { Sol. nitrogen } \\
\mathbf{g} / \mathbf{1 0 0 g}\end{array}$ & $\begin{array}{c}\text { Insol nitrogen } \\
\mathbf{\%}\end{array}$ & $\begin{array}{c}\text { Total nitrogen } \\
\mathbf{\%}\end{array}$ & $\begin{array}{c}\text { Sol /insol. } \\
\text { Ratio }\end{array}$ \\
\hline Control & 0.469 & 6.15 & 6.62 & 0.077 \\
\hline $\mathbf{0 . 2 \%}$ novatreen & 0.454 & 6.23 & 6.68 & 0.073 \\
\hline $\mathbf{0 . 4 \%}$ novatreen & 0.441 & 6.31 & 6.75 & 0.070 \\
\hline $\mathbf{0 . 2 \%}$ potassen & 0.485 & 6.11 & 6.60 & 0.079 \\
\hline $\mathbf{0 . 4 \%}$ potassen & 0.494 & 6.08 & 6.57 & 0.081 \\
\hline
\end{tabular}

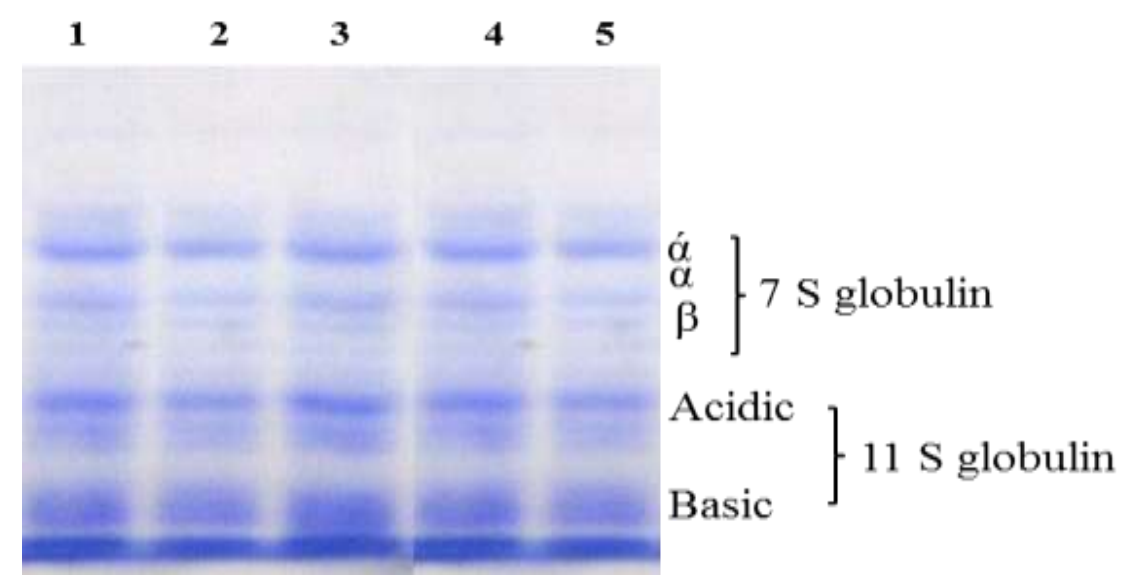

Figure 1. SDS-PAGE of different soybean protein samples Lane (1):..., Lane (2):.......

globulin subunits ranges from 50 to $65 \mathrm{KD}$. $11 \mathrm{~S}$ globulin showed pure band with the two main subunits ,basic and acidic These results were in accordance with those obtained by Sitohy and Osman (2010); Sitohy et al (2017).

Results of protein fractionation according to solubility in different solvents (water, acetic acid and $\mathrm{NaOH}$ ) at ratio of $1: 25 \mathrm{w} / \mathrm{v}$ for each solvent, were illustrated on Table (3). Solubility percentage of all applications and control recorded highest values $(75.9,75.6,75.2,77.0$ and $78.4 \%$, respectively) compering with solubility in acetic acid solution (15.1, 14.9, 
Table(3): Effect of novatreen and potassen foliar on the percentages of different soluble protein fractions of soybean seeds .

\begin{tabular}{|l|c|c|c|}
\hline Treatments & $\begin{array}{c}\text { Water sol. } \\
\text { fractions } \\
\mathbf{1 : 2 5} \text { w/v }\end{array}$ & $\begin{array}{c}\text { Acetic acid 70\% } \\
\mathbf{1 : 2 5} \mathbf{w / v}\end{array}$ & $\begin{array}{c}\text { Sodium } \\
\text { hydroxide 0.1N } \\
\mathbf{1 : 2 5} \mathbf{~ w / v}\end{array}$ \\
\hline Control & 75.9 & 15.1 & 8.4 \\
\hline $\mathbf{0 . 2 \%}$ novatreen & 75.6 & 14.9 & 9.3 \\
\hline $\mathbf{0 . 4 \%}$ novatreen & 75.2 & 14.7 & 10.1 \\
\hline $\mathbf{0 . 2 \%}$ potassen & 77.0 & 13.9 & 8.2 \\
\hline $\mathbf{0 . 4 \%}$ potassen & 78.4 & 13.2 & 8.3 \\
\hline
\end{tabular}

14.7, 13.9 and $13.2 \%$ respectively) and solubility percentages in sodium hydroxide solution $(8.4,9.3,10.1,8.2$ and $8.3 \%$, respectively). These meaning that protein of soybean seeds has hydrophilic characteristics attributed to its composition mainly of hydrophilic amino acids , as well as higher percentage of basic amino acids than acidic amino acids (Table 3) .These data were in accordance with those obtained by Sitohy and Osman,(2010) and Sitohy et al . (2017).

Some characteristics of soybean oil (yield, acid value ,saponification value ,iodine value and free acid percentages ) were showed in Table (4). It can be noticed that potassen applications, either with $0.2 \%$ or with $0.4 \%$ gave higher values of oil yield (19.32 and $19.85 \%$ respectively) than both control or novatreen applications, which had in significant effect on soybean oil yield (18.52,18.26 and $18.42 \%$ respectively). In the same table (4) all application gave oil with lower acid values than control $(2.24,2.06,2.15$ ,2.01 and 2.10 ), that meaning ,both novatreen and potassen applications in this study improved storage time of oil .Saponification values of novatreen and potassen application with $0.2 \%$ were increased the incorporation of short chain fatty acids in oil (193.32 and 198.23 respectively) comparing with control (185.25).

Iodine values of treatments showed that potassen application was increased unsaturated fatty acid content of soybean oil either at $0.2 \%$ or $0.4 \%$ (183.20 and 180.25, respectively) as comparing with control and novatreen application results $(179.42,176.25$ and 173.4 respectively ). Results of fatty acids percentages (Table 4 ) stated that values of potassen application were lower than those obtained with control or with novatreen treatments $(1.01,1.06,1.171 .03$ and 1.18 respectively) and it can be noticed that these results were in accordance with those reported for acid values in 
Table(4): Effect of novatreen and potassen foliars on the oil constant and some constants of soybean oil.

\begin{tabular}{|l|c|c|c|c|c|}
\hline Treatments & $\begin{array}{c}\text { Oil } \\
\text { content } \\
\text { \% }\end{array}$ & $\begin{array}{c}\text { Acid } \\
\text { value }\end{array}$ & $\begin{array}{c}\text { Saponificatio } \\
\text { n value }\end{array}$ & $\begin{array}{c}\text { Iodine } \\
\text { value }\end{array}$ & $\begin{array}{c}\text { Free fatty } \\
\text { acids \% }\end{array}$ \\
\hline Control & 18.52 & 2.24 & 185.25 & 179.42 & 1.17 \\
\hline $\begin{array}{l}\mathbf{0 . 2 \%} \\
\text { novatreen }\end{array}$ & 18.26 & 2.06 & 193.32 & 176.25 & 1.03 \\
\hline $\begin{array}{l}\mathbf{0 . 4 \%} \\
\text { novatreen }\end{array}$ & 18.42 & 2.15 & 182.29 & 173.40 & 1.18 \\
\hline $\begin{array}{l}\mathbf{0 . 2 \%} \\
\text { potassen }\end{array}$ & 19.32 & 2.01 & 198.23 & 183.20 & 1.01 \\
\hline $\begin{array}{l}\mathbf{0 . 4 \%} \\
\text { potassen }\end{array}$ & 19.85 & 2.10 & 184.40 & 180.25 & 1.06 \\
\hline
\end{tabular}

this study ,also obtained results were in agreement with those reported by Mudlagiri et al. , (2012) and Manju et al. (2014).

The effect of foliar application on the content of some elements in soybean seeds are shown in Table (5). It seems that all treatments improved

Table(5): Effect of novatreen and potassen foliars on the contents of some elements of seeds .

\begin{tabular}{|l|l|l|l|l|l|l|}
\hline Treatments & $\begin{array}{c}\text { Phosphorus } \\
\mathbf{\%}\end{array}$ & $\begin{array}{c}\text { Potassium } \\
\mathbf{\%}\end{array}$ & $\begin{array}{c}\text { Sodium } \\
\mathbf{\%}\end{array}$ & $\begin{array}{c}\text { Ferrous } \\
\mathbf{M g} \\
\mathbf{/ 1 0 0 g m}\end{array}$ & $\begin{array}{c}\text { Zinc } \\
\mathbf{M g} \\
\mathbf{/ 1 0 0 g m}\end{array}$ & $\begin{array}{c}\text { Manganese } \\
\mathbf{M g} \\
\mathbf{/ 1 0 0 g m}\end{array}$ \\
\hline Control & 0.136 & 2.98 & 0.91 & 183.9 & 3.3 & 52.97 \\
\hline $\begin{array}{l}\mathbf{0 . 2 \%} \\
\text { novatreen }\end{array}$ & 0.165 & 2.98 & 1.50 & 181.2 & 3.5 & 42.28 \\
\hline $\begin{array}{l}\mathbf{0 . 4 \%} \\
\text { novatreen }\end{array}$ & 0.161 & 3.58 & 1.70 & 148.9 & 3.7 & 37.53 \\
\hline $\begin{array}{l}\mathbf{0 . 2 \%} \\
\text { potassen }\end{array}$ & 0.155 & 4.18 & 1.70 & 146.2 & 4.5 & 31.54 \\
\hline $\begin{array}{l}\mathbf{0 . 4 \%} \\
\text { potassen }\end{array}$ & 0.155 & 4.48 & 2.00 & 154.3 & 3.4 & 30.40 \\
\hline
\end{tabular}

the content of $\mathrm{P}, \mathrm{K}$, and $\mathrm{Na}$ in seeds. The highest values of $\mathrm{K}$ and $\mathrm{Na}$ were recorded by $0.4 \%$ potassen, foliar treatment while the highest value of $\mathrm{P}$ was obtained by $0.2 \%$ novatreen treatment. These results indicated that the 
mobilization of assimilated elements to the seeds and its accumulation there were increased. Similar results were previously reported by Antonio (2012).

The content of $\mathrm{Fe}$ and $\mathrm{Mn}$ of seeds reduced by all treatments as compared with control, but the content of $\mathrm{Zn}$ increased. These results are in agreement with those obtained by Soheil et al (2013) who found that $\mathrm{Zn}$ application , $\mathrm{Zn} / \mathrm{Fe}$ and $\mathrm{Zn} / \mathrm{Mn}$ increased the content of nutrients of soybean seeds.

Conclusively, It is recommended to spray the novatreen and potasen compound on the plants after 30 days of cultivation with a concentration of $0.4 \%$ to obtain the highest productivity of the seed yield as well as the quality of the protein content, oil and nutrients necessary for the process of metabolism in the plant.

\section{REFERANCES}

Abd-elmohsin ,R.K.(2016). Effect of Biofertilizer, nitrogen and Phosphorus on irrigated soybean (Glycin max) in Gezera-sudan, . Journal of Agricultural and Biological Science, 11(9): 351-359.

Agiza, A. A.; El-Henidy, M. and Elbrahim, M.(1960). The determination of the different fractions of phosphorus. Fac of Agric., Cairo Univ., Bull., 1(2)2-7.

Antonio ,M. (2012). Potassium effects on yield corn and soybean on potassium uptake and recycling to the oil low slate, Ag Engineering, Agronomy. Central Lowa And Bio Century Research Farms.

A.O.A.C.(1970). Association Of Official Analytical Chemts. Official Methods Of Analysis. the ed Washington's, USA.

Chapman, H. D. and Parker, P. P. (1961). Methods Of Analysis Of Soil ,Plant And Water. University of California, USA.

Faisal, Z. ; Mansor, M.; Azini, M. and Khuram, M. (2013). Soybean response to micro nutrients. Turkish Journal Of Field Crops, 18 (2):134-38.

Hamdia,A. S. M. (2013). The physiological response of wheat plants to exogensus application of GA3 or IAA. International Journal Of Plant Physiology And Biochemistry, 5(4):58-64.2013.

Heidarian, A. R.;Khodad, M.; Anir, P. L. and Faezeh, A. M.(2011). Investigation $\mathrm{Fe}$ and $\mathrm{Zn}$ foliar application on yield and its components of soybean at different growth stages. J. of Agricultural Biotechnology Developments, 2(9):189. 
Lammli, U. K. (1970). Methods Of Protein Analysis, Nature (London) 227680.(C.F.Keres,I.1984). Akademia Arkado, Budapest.

Manju.P.; Mudlgiri. B. and Nacer, B. (2014). Effect of foliar and soil application of potassium fertilizer on soybean seeds, protein ,oil , fatty acids and minerals. American Journal Of Plant Science, (5):541-548.

Mannan,M,A.(2014). Foliar and soil fertilization effect on seed yield and protein content of soybean. Bangludesh Agrron. J., 62-72.

Mudlagiri,B.G;Manju,Pand Nacer,B.(2012). Effect of chelating agentson on protein, oil, fatty acids and minerals in soybean seed. Agricultural Sciences, 3 (4):517-523.

Nacer, G.; Xinbua, Yoalemu, M. ; Angeid, M. ;Don, D.J Tyler ;A. and Krishua, N. R.(2013). Soybean seed protein, oil, fatty acids and iso Sciences, 4:976-988

Sitohy, M. and Osman, A. (2010). Antimicrobial activity of native and esterified legume proteins against gram negative and gram positive bacteria. Food Chemistry, 120: 66-75.

Sitohy, M.; Mahgoub, S. A and Osman, A. (2017). In vitro and in situ antimicrobial action and mechanism of glycinin and its basic subunits. International Journal Of Food Microbiology, 154:14-29.

Soheil, K.; Ghorban, N.; Hosein, H.; Farokh, D. and Badak, D.(2013). Micronutrients distribution in soybean plant with $\mathrm{Zn}, \mathrm{Fe}$ and $\mathrm{Mn}$ application. Annual Review And Research In Biology, 3(2):83-91.

Yosef,S.; Azam, H.; Khosro,M.; Mansour, S.; Gholamereza, H.; Shiva, K. and Masomeh, K. (2012). Effect of $\mathrm{N}$ fertilizer and foliar applied fertilizer at various reproductive stage on yield and chemical composition of soybean seed. African Journal Biotochnology, 11(40): 9599-9605. 


\section{دراسات كيميائية حيوية علي تاثير بعض مركبات الرش علي محصول بذور فول الصويا ونوعيته}

\section{عبدالعزيز لطفى شرف}

قسم علوم الار اضي و المياه- كلية التكنولوجيا و التنمية - جامعة الزقازيق- مصر.

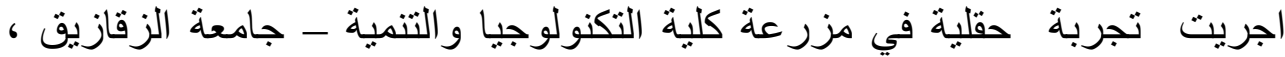

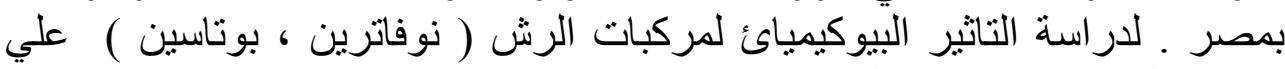

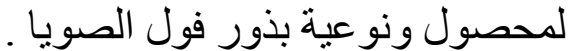

تم رش نباتات فول الصويا بمركب النوفاترين و البو تاسين بتركيز ات

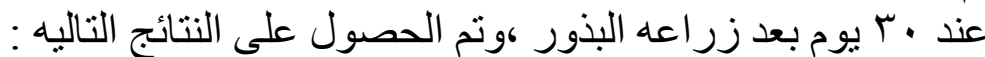

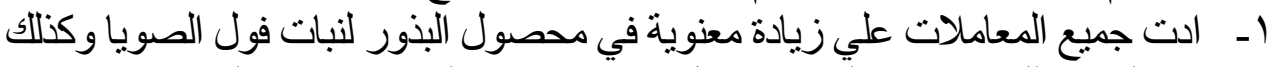

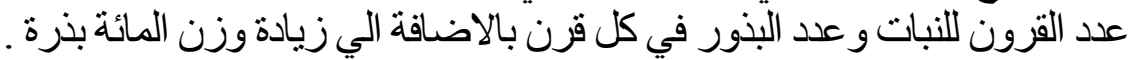

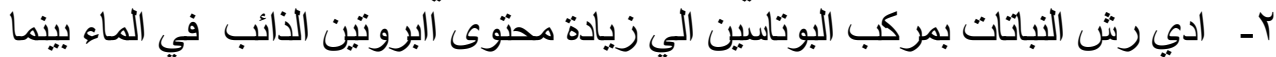

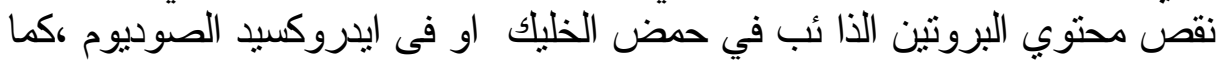

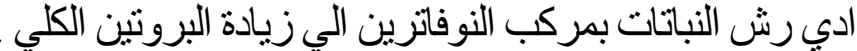

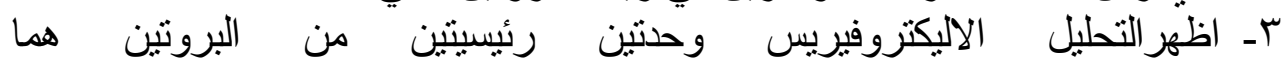
(globulin 11S , 7S )

عـ ادي رش النباتات بمركب النوفاترين الي انخفاض طفيف في محتوى بذور فول الصويا

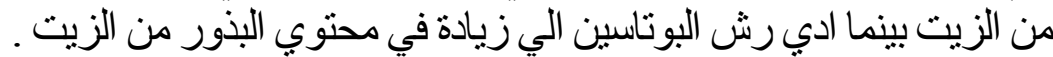

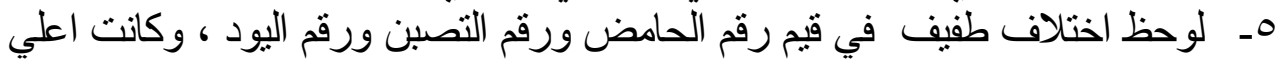

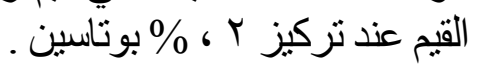
ا-ـ ادي رش النباتات بالنوفاترين والبوتانين النين الي تحسن محتوي البذور من الفوسفور

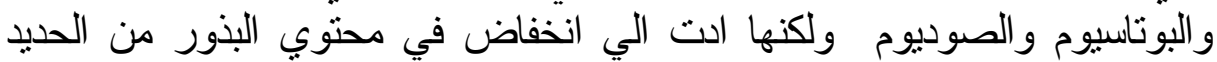

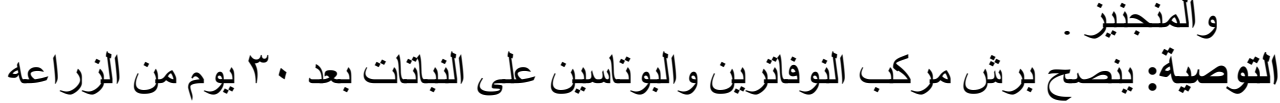

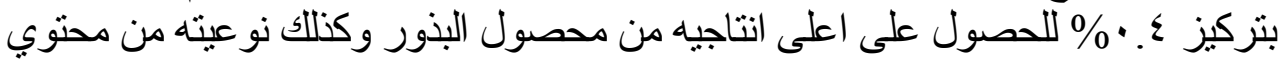
البروتين والزيت و العناصر الغذائيه اللازمه لعطليه التمثيل الغذائي في النبات ـ التئ 